\title{
Kajian Antioksidan, Total Fenol \& Total Flavonoid Jamu Selokarang yang diformulasi dengan Jinten Hitam (Nigella sativa)
}

Sukardi $1^{*}$, Noer Iqbal Arief ${ }^{1}$, Sri Winarsih ${ }^{1}$

${ }^{1}$ Prodi Teknologi Pangan, Fakultas Pertanian Peternakan, Universitas Muhammadiyah Malang, Malang, Indonesia

*Corresponding author email : sukardi@umm.ac.id

\begin{abstract}
Abstrcact. Jamu Selokarang is one of the traditional drinks originating from an area, namely Madura, the ingredients used in the manufacture of Jamu Selokarang are turmeric, ginger, ginger, betel leaf, soursop leaves, cloves, nutmeg, coriander, temu ireng and ginger. The ingredients used in the manufacture of herbal medicine selokarang contain a lot of antioxidants and essential oils. Testing is needed to determine the antioxidant activity contained in the herbal medicine selokarang. This study aims to determine the effect of substitution of jamu selokarang on antioxidant compounds, total phenols, flavonoids, ash content and water content.

This study used a simple completely randomized design method (simple CRD) with a single factor, namely the black cumin formulation of $0 \%, 2 \%, 4 \%, 6 \%$ and $8 \%$ which were included in jamu selokarang. The research was repeated 3 times. The parameters observed were: water content, ash content, antioxidants, total phenols, and flavonoids. The results showed that the substitution had a significant effect on water content, ash content and antioxidant activity, while the total phenol and flavonoid analysis had no significant effect. Treatment $0 \%$ black cumin had water content of 2.68\%; Ash content of 7,90\%; DPPH anti-oxidant for 49.08\%; antioxidant FRAP $26.25 \mu \mathrm{gAAE} / \mathrm{mL}$; total phenol was $2.05 \mu \mathrm{gGAE} / \mathrm{mg}$, and total flavonoids was $0.91 \mathrm{\mu gQAE} / \mathrm{mg}$.

Keywords: antioxidant activity, black cumin substitution (Nigella sativa), Jamu selokarang, total flavonoids, total phenol
\end{abstract}

\section{PENDAHULUAN.}

Jamu merupakan salah minuman tradisonal yang memiliki beberapa manfaat jika dikonsumsi. Jamu sendiri terdiri dari berbagai rempah-rempah atau tanaman toga yang bermanfaat bagi kesehatan tubuh manusia. Jamu telah menjadi bagian budaya dan kekayaan alam Indonesia dan pola konsumsi Jamu oleh masyarakat Indonesia cukup tinggi hal ini dapat dilihat pada data Riset Kesehatan Dasar 2010 menunjukkan bahwa 56\% masyarakat Indonesia pernah mengkonsumsi jamu dan untuk provinsi Jawa Timur mencapai 71,84\%. Tingginya tingkat konsumsi jamu dikarenakan ramuan tradisional ini memiliki manfaat yang secara langsung dirasakan oleh pengkonsumsinya, dimana sebagian besar $(95,60 \%)$ pengguna jamu menyatakan bahwa ramuan ini mampu meningkatkan daya tahan dan 
perawatan tubuh. Kebiasaan masyarakat untuk mengkonsumsi jamu sudah ada sejak jaman dahulu atau jaman nenek moyang yang sudah terbiasa memanfaatkan tumbuhan obat - obatan atau sering disebut tanaman toga sehingga menjadikan kebudayaan atau adat pada daerah tersebut. Salah satu daerah yang kental atau terkenal akan jamu nya ialah Madura.

Jamu selokarang merupakan salah satu jamu yang berasal dari jawa timur tepatnya madura. Bahan yang digunakan dalam pembuatan jamu selokarang ialah jahe, kunyit, temulawak, bawang putih, daun sirih, daun sirsak, ketumbar, pala, temu hitam, cengkeh. Salah satu bahan yang digunakan ialah jahe yang mengandung senyawa antioksidan tinggi golongan flavonoid seperti kuersetin, catechin, rutin, epicathecin, naringenin, dan kaempferol (Ghasemzadeh,2010). Bahan yang digunakan memiliki aktivitas antioksidan yang berbeda-beda. Antioksidan didalam bahan berfungsi untuk menghambat radikal bebas yang masuk kedalam tubuh manusia. Dari hasil survei lapang jamu selokarang memiliki manfaat seperti menurunkan darah tinggi, mengobati sariawan, batuk dan melegakan saluran pernafasan. Penambahan jinten hitam pada jamu selokarang dilakukan untuk meningkatkan aktivitas antioksidan pada jamu selokarang, secara kimia belum diketahui senyawa yang terkandung didalam jamu selokarang, dengan demikian perlu adanya uji lanjut untuk mengetahui senyawa kimia secara klinis agar mengetahui manfaat dari jamu selokarang.

\section{METODOLOGI PENELITIAN}

Bahan

Bahan yang digunakan dalam penelitian ini yaitu jamu selokarang dari Sumenep Madura, Larutan DPPH, Aquades, etanol 96\% $\left(\mathrm{C}_{2} \mathrm{H}_{5} \mathrm{OH}\right)$, larutan $\mathrm{AlCl}_{3}$, Reagen Folin-Ciocalteu, aquades $\left(\mathrm{H}_{2} \mathrm{O}\right)$, feri sianida $\left(\mathrm{FeCl}_{3}\right)$ p.a, asam trikloroasetat/TCA $\left(\mathrm{C}_{2} \mathrm{HCl}_{3} \mathrm{O}_{2}\right)$, sodium asetat $\left(\mathrm{CH}_{3} \mathrm{COONa}\right)$ teknis, alumunium klorida $\left(\mathrm{AlCl}_{3}\right)$ p.a, sodium hidroksida $(\mathrm{NaOH})$ teknis, potasium dihidrogen fosfat $\left(\mathrm{KH}_{2} \mathrm{PO}_{4}\right)$ teknis, sodium karbonat $\left(\mathrm{Na}_{2} \mathrm{CO}_{3}\right)$ p.a, asam oksalat $\left(\mathrm{C}_{2} \mathrm{H}_{2} \mathrm{O}_{4}\right)$ p.a, asam galat $\left(\mathrm{C}_{7} \mathrm{H}_{6} \mathrm{O}_{5}\right)$ p.a, kuersetin $\left(\mathrm{C}_{15} \mathrm{H}_{10} \mathrm{O}_{7}\right)$ p.a, dan asam askorbat $\left(\mathrm{C}_{6} \mathrm{H}_{8} \mathrm{O}_{6}\right)$ teknis.

Alat

Alat yang dihunakan pada penelitian ini yaitu adalah spektrofotometer thermos spectronic (GENESYS 20), desikator Glaswerk Wertheim 6132, alumunium foil, kertas saring, centrifuge, timbangan analitik, showcase, rak tabung reaksi, vortex, tanur, oven, mikro pipet, spatula, batang pengaduk, centrifuge tube, botol kaca gelap, sarung tangan kain, blue tip, alat-alat gelas seperti cawan, batang pengaduk, pipet ukur, labu ukur, gelas ukur, gelas beker, erlenmeyer, botol vial, botol kaca gelap, dan tabung reaksi. 


\section{Pembuatan jamu selokarang}

Pada pembuatan jamu selokarang bahan yang digunakan ialah jahe, kunyit, temulawak, bawang putih, daun sirih, daun sirsak, ketumbar, pala, temu hitam, cengkeh dengan perbandingan setiap bahan $1: 1$. Kulit bahan dibesihkan kemudian bahan dipotong kecil untuk mempercepat proses pengeringan waktu pengeringan selama 2 X 24 jam dengan menggunakan sinar matahari setelah itu dihaluskan menggunakan blender dan dicampurkan dengan jinten hitam sebesar $0 \%, 2 \%, 4 \%, 6 \%$ dan $8 \%$. Jamu selokarang yang dihasilkan kemudian dianalisa.

\section{Parameter penelitian}

Parameter penelitian yang digunakan antara lain uji kimia Pengujian sifat kimia berupa Analisa kadar Air Pengeringan Oven (Andarwulan, 2011), analisa kadar Abu Pengeringan Tanur (SNI 01-2891-1992), Analisa Antioksidan IC $_{50}$ (Nora Al-Hadiwi, 2014), Analisa aktivitas Antioksidan (FRAP) (Vifta, 2020), Analisa total fenol (Al-Owaisi, 2014), Analisa total flavonoid (Haeria, 2016).

\section{Rancangan Percobaan dan Analisa Data}

Rancangan percobaan yang diterapkan dalam penelitian ini adalah Rancangan Acak Lengkap (RAL) Sederhana. Faktor 1 yang digunakan adalah penambahan jinten hitam sebanyak 0\%, 2\%, 4\%, 6\% dan 8. Bahan baku yang digunakan bersifat homogen yaitu jahe, kunyit, temulawak, bawang putih, daun sirih, daun sirsak, ketumbar, pala, temu hitam, cengkeh. Ulangan pada masing-masing perlakuan akan dilakukan sebanyak 3 kali.

Pengolahan data dilakukan dengan menggunakan analisis ragam pada taraf $5 \%$ dan $1 \%$. Selanjutnya bila terjadi beda nyata atau interaksi pada masing-masing perlakuan maka data yang sudah diperoleh akan dilanjutkan dengan uji pembeda menggunakan uji DMRT (Duncan's Multiple Range Test) pada taraf $5 \%$, dan $1 \%$.

\section{HASIL DAN PEMBAHASAN \\ Hasil Analisa Kadar Air}

Berdasarkan analisa sidik ragam, diketahui bahwa konsentrasi jintan hitam berbeda nyata $(\mathrm{p}<0,01)$ terhadap kadar air jinten hitam. Nilai kadar air terbesar ialah jinten hitam $6 \%$ sebesar $2.85 \%$ dan nilai kadar air terkecil pada perlakuan jinten hitam 4\% sebesar $2.47 \%$. Selisih dari setiap perlakuan $\pm 0.04 \%-0.38 \%$. Jika dilihat dari hasil analisa kadar air dari semua sampel $<10 \%$ yang dapat dinyatakan sesuai dengan standard (BPOM, 2019). 


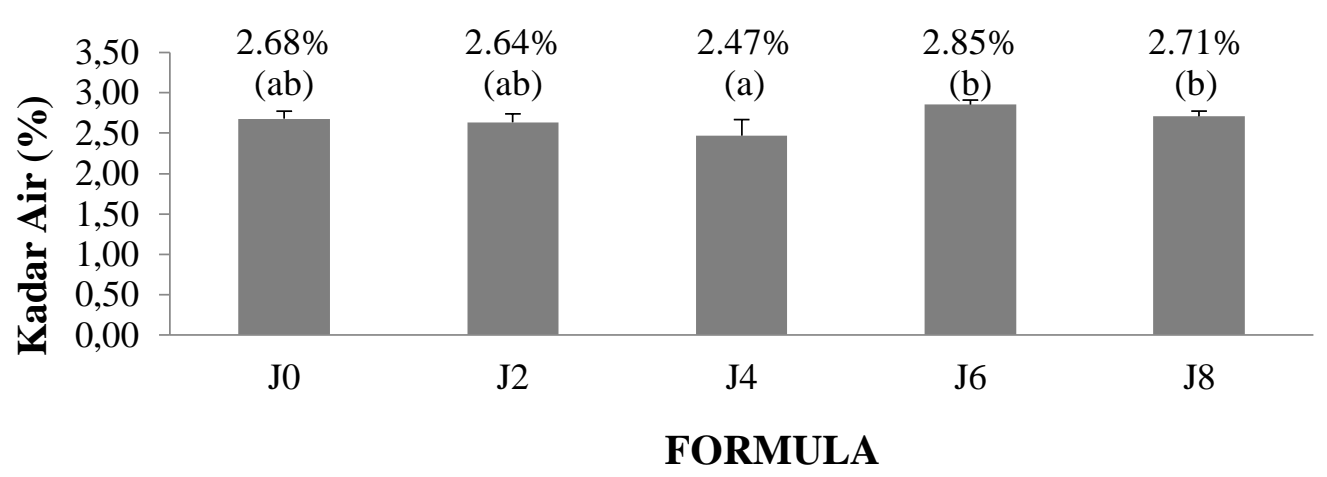

Gambar 1.Histogram analisa kadar air

Keterangan : J0 : jinten hitam 0\%, J2 : jinten hitam 2\%, J4 : jinten hitam 4\%, J6 : jinten hitam 6\% dan J8 : jinten hitam 8\%.

Prinsip analisa kadar air dengan pengeringan oven ialah dengan cara penguapan air yang berada dalam bahan dengan menggunakan pemanasan pada suhu $100-105^{\circ} \mathrm{C}$ dan tekanan $760 \mathrm{mmHg}$ selama 5-6 jam. Proses pengeringan jamu selokarang dilakukan secara tradisional menggunakan sinar matahari selama 48 jam hal ini dilakukan agar kadar air didalam bahan jamu selokarang menurun dengan demikian jamu selokarang memiliki daya simpan yang lebih lama selain itu kadar air yang kecil dapat menghambat bakteri.

Penurunan kadar air dapat disebabkan oleh luas permukaan bahan, semakin besar luas permukaan bahan maka kadar air dalam bahan mudah untuk diuapkan hal ini dikarenakan udara panas akan lebih cepat masuk dalam pori pori bahan. Hal ini sesuai dengan pernyataan ( Dimas, 2008 ), mengungkapkan bahwa pengirisan bahan yang dikeringkan akan memperluas permukaan bahan dan permukaan yang luas dapat memudahkan air keluar. Penurunan kadar air didalam bahan dapat disebebkan oleh kondisi lingkungan bahan dimana penguapan air didalam bahan dipengaruhi oleh suhu pengeringan menurut Widjanarko (2012), laju penguapan disamping dipengaruhi oleh tingkat kelembaban juga dipengaruhi oleh suhu di sekitar bahan yang dikeringkan. Nilai kadar air jamu selokarang sesuai dengan standar BPOM sebesar $<10 \%$.

\section{Hasil Analisa Kadar Abu}

Berdasarkan analisa sidik ragam, diketahui bahwa konsentrasi jintan hitam berbeda nyata $(p<0,01)$ terhadap kadar abu jinten hitam. Nilai kadar abu terbesar ialah jinten hitam $0 \%$ sebesar 7.89\% dan nilai kadar abu terkecil pada perlakuan jinten hitam $8 \%$ sebesar $7.47 \%$. Selisih dari setiap perlakuan $\pm 0.06 \%$ $0.25 \%$. Prinsip kadar abu metode tanur ialah dengan cara mengoksidasi semua zat organik yang terdapat didalam bahan pada suhu tinggi, yakni sekitar 500$600^{\circ} \mathrm{C}$ dan kemudian melakukan penimbangan zat yang tertinggal setelah proses pengabuan selesai 


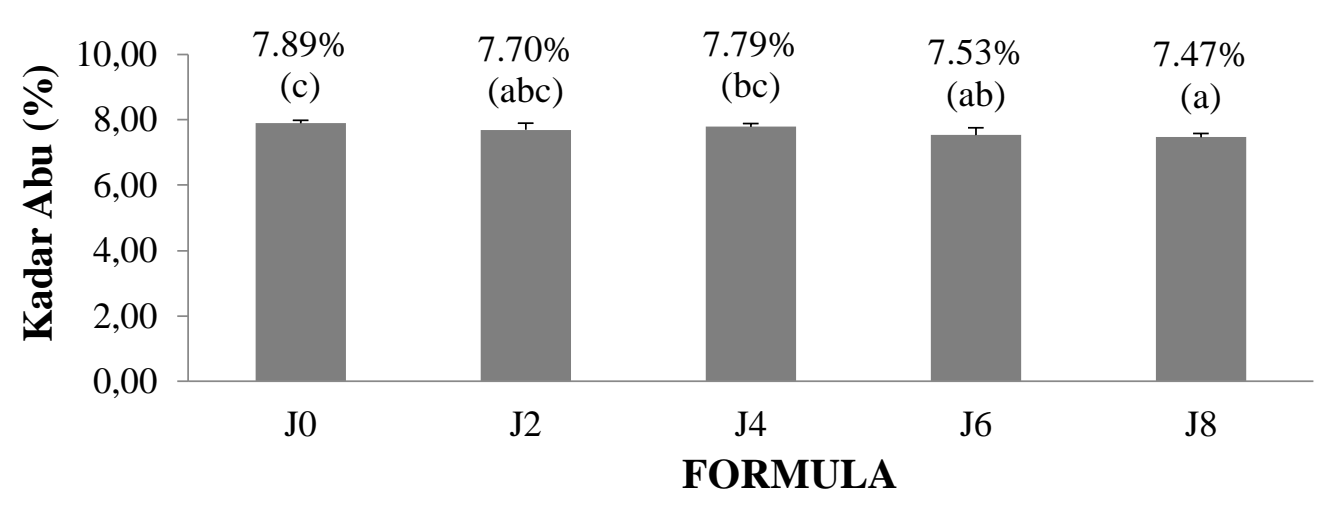

Gambar 2. Histogram analisa kadar abu

Keterangan : J0 : jinten hitam 0\%, J2 : jinten hitam $2 \%$, J4 : jinten hitam $4 \%$, J6 : jinten hitam $6 \%$ dan J8 : jinten hitam 8\%.

Kadar abu didalam bahan dapat menunjukkan kandungan mineral yang terkandung didalamnya, selain itu dapat menunjukkan kemurnian serta kebersihan dari bahan itu seendiri. Kandungan anorganik pada bahan tidak terbakar menjadi abu akan tetapi pada kandungan organik terbakar menjadi abu, kadar abu memiliki hubungan dengan mineral didalam bahan (Akbar,2016). Pengujian kadar abu dapat menentukan kualitas bahan, kebersihan bahan yang digunakan serta keaslian bahan yang digunakan. Selain itu, Kadar abu dari suatu bahan biasanya menunjukkan kadar mineral, kemurnian, serta kebersihan suatu bahan yang dihasilkan.

Pengujian kadar abu dapat menentukan kualitas bahan, kebersihan bahan yang digunakan serta keaslian bahan yang digunakan. Selain itu, Kadar abu dari suatu bahan biasanya menunjukkan kadar mineral, kemurnian, serta kebersihan suatu bahan yang dihasilkan. Mengatakan bahwa kandungan mineral pada bahan berbeda - beda, Kandungan abu dapat digunakan untuk memperkirakan kandungan dan keaslian bahan yang digunakan (Amaliana, 2015).

\section{Hasil Analisa Total Fenol}

Berdasarkan analisa sidik ragam, diketahui bahwa konsentrasi jintan hitam tidak berbeda nyata $(p<0,01)$ terhadap total fenol. Hasil Analisa total fenol terbesar pada perlakuan jinten hitam $0 \%$ sebesar $2.05 \mathrm{mg} \mathrm{GAE} / \mathrm{g}$ dan terkecil pada perlakuan jinten hitam $6 \%$ sebesar $1.61 \mathrm{mg} \mathrm{GAE} / \mathrm{g}$. Selisih dari setiap perlakuan $\pm 0.05 \mathrm{mg} \mathrm{GAE} / \mathrm{g}-0.29 \mathrm{mg} \mathrm{GAE} / \mathrm{g}$. 


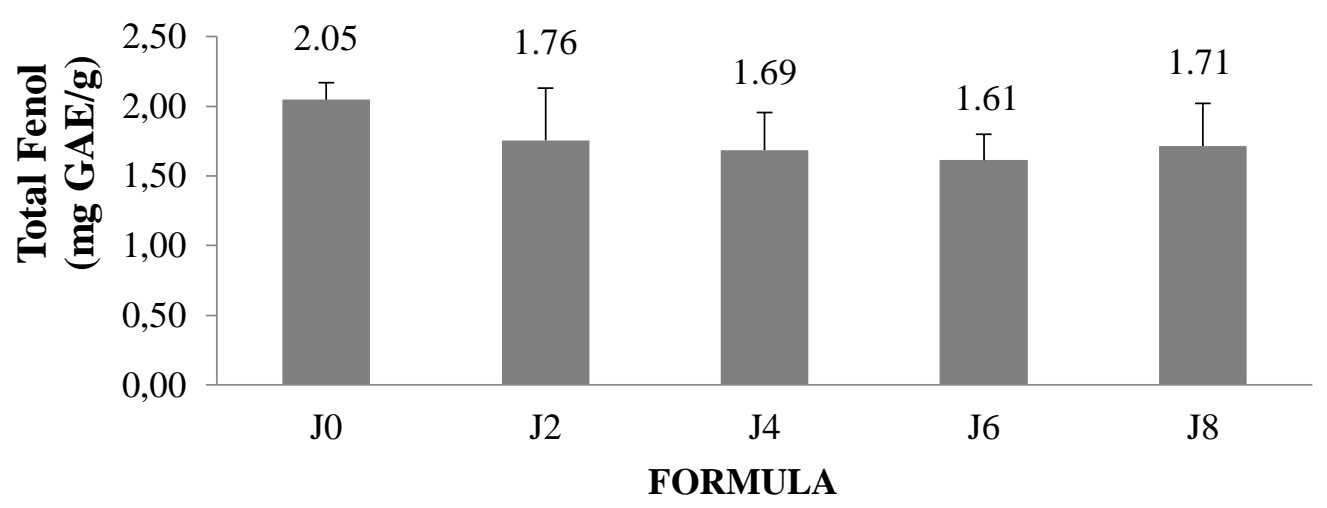

Gambar 3. Histogram analisa total fenol

Keterangan : J0 : jinten hitam 0\%, J2 : jinten hitam 2\%, J4 : jinten hitam 4\%, J6 : jinten hitam 6\% dan J8: jinten hitam 8\%.

Dari hasil analisa terdapat senyawa fenol yang terkandung didalam bahan hal ini terlihat pada perubahan warna sampel setelah penambahan larutan FolinCiocalteu dan natrium karbonat yang berubah menjadi kebiruan perubahan ini terjadi karena tereduksinya asam fosfomolibdat-fosfotungstat dalam larutan Folin-Ciocalteu oleh senyawa polifenol menjadi molybdenum blue membentuk kompleks berwarna biru (Kate, 2014). Semakin tinggi kadar fenolik dalam suatu sampel maka warna yang terbentuk semakin gelap. Senyawa fenol berkorelasi dengan antioksidan menurut Rafi (2012) menyatakan bahwa aktivitas antioksidan suatu tumbuhan dapat berkorelasi dengan kadar senyawa fenolik didalamnya. Senyawa fenol memiliki gugus - $\mathrm{OH}$ pada struktur cincin benzenanya, dimana atom $\mathrm{H}$ dari gugus $\mathrm{OH}$ memiliki aktivitas antioksidan yang dapat menangkal dan meredam radikal bebas (Arifin, 2019).

Total fenol memiliki hubungan dengan aktivitas antioksidan didalam bahan hal ini disebebkan oleh senyawa fenolik dapat berperan dalam menentukan besarnya aktivitas antioksidan tidak hanya flavonoid yang memberikan kontribusi dalam aktivitas antioksidan, dengan demikian penurunan total fenol pada perlakuan selanjutnya dapat disebabkan oleh sifat antioksidan yang larut dalam air dan juga mudah mengalami oksidasi hal ini sesuai dengan pernyataan kristina ( 2016 ) yang menyatakan Fenol cenderung mudah larut dalam air karena berikatan dengan gula sebagai glikosida atau terdapat dalam vakuola sel dan Prima (2010) yang menyatakan senyawa Fenol yang dibiarkan diudara terbuka cepat berubah warna karena pembentukan hasil-hasil oksidasi. Asam galat digunakan sebagai standar dalam pengujian ini dikarenakan mudah diperoleh, stabil, murni, dan lebih murah (Lestari, 2015 dalam Widyasanti, 2018). 


\section{Hasil Analisa Total Flavonoid}

Berdasarkan analisa sidik ragam, diketahui bahwa konsentrasi jintan hitam tidak berbeda nyata $(p<0,01)$ terhadap flavonoid. Hasil analisa total flavonoid terbesar pada perlakuan jinten hitam 0\% sebesar $0.91 \mathrm{mgQAE} / \mathrm{g}$ dan terkecil pada perlakuan jinten hitam $8 \%$ sebesar $0.79 \mathrm{mgQAE} / \mathrm{g}$. Selisih dari setiap perlakuan \pm $0.01 \mathrm{mgQAE} / \mathrm{g}$ - 0.06mgQAE/g. larutan sampel ditambahkan $\mathrm{AlCl}_{3}$ yang dapat membentuk kompleks, sehingga terjadi pergeseran panjang gelombang ke arah visible yang ditandai dengan sampel yang menguning sedangkan penambahan kalium asetat bertujuan untuk mempertahankan panjang gelombang pada daerah visible.

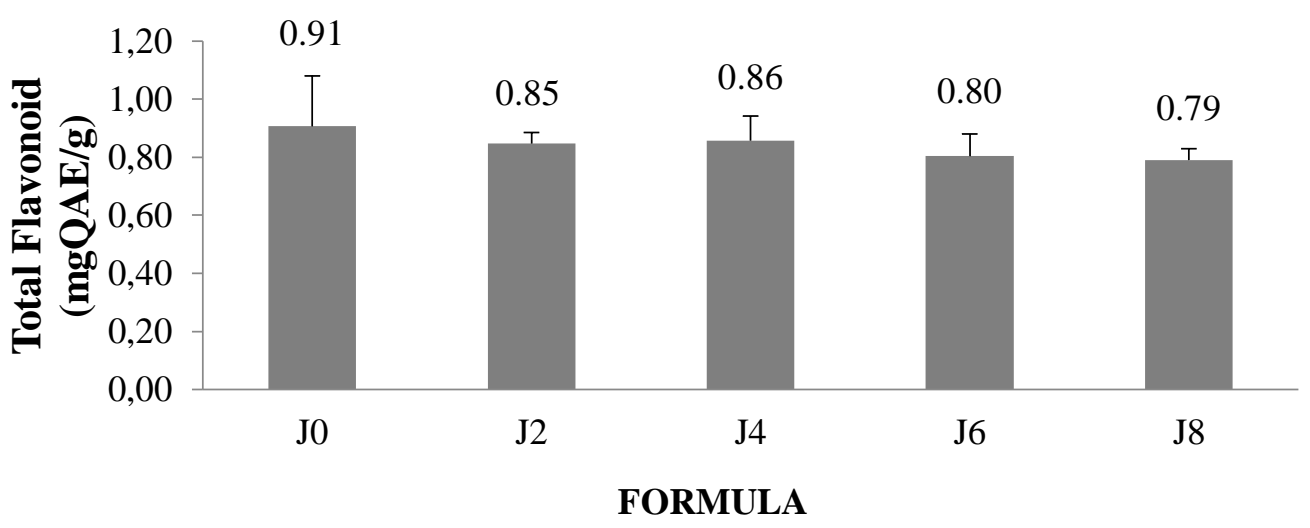

Gambar 4. Histogram analisa total flavonoid

Keterangan : J0 : jinten hitam 0\%, J2 : jinten hitam 2\%, J4 : jinten hitam 4\%, J6 : jinten hitam $6 \%$ dan J8 : jinten hitam 8\%.

Penurunan total flavonoid dapat dipengaruhi oksidasi flavonoid dan polifenol didalam bahan sehingga terjadi perubahan sifat dan fungsi dari bahan hal ini yang menyebabkan pada proses oksidasi senyawa flavonoid maupun polifenol, dimana atom $\mathrm{H}$ pada gugus $\mathrm{OH}$ diambil oleh senyawa pengoksidasi, dengan terurainya struktur maka terjadi perubahan sifat dan fungsinya sebagai bahan aktif akan berkurang bahkan hilang. Analisa senyawa flavonoid dilakukan dengan menggunakan alat spektrometeri UV - VIS hal ini dikarenakan senyawa flavonoid mengandung system aromatik yang terkonjungasi sehingga menunjukkan pita serapan kuat pada daerah spektrum uv dan spektrum sinar tampak. Prinsip kadar flavonoid metode aluminium klorida ialah terjadinya pembentukan kompleks antara gugus keto pada C-4 dan memiliki gugus hidroksil pada atom C-3 atau C-5 yang bertetangga dari flavon dan flavonol (Azizah dan Faramayuda, 2014).

Flavonoid dan polifenol yang mengalami perubahan struktur akan menjadi tidak dikenal sebagai senyawa flavonoid dan polifenol pada hasil analisis kandungan senyawa tersebut, dimana semakin banyak atom $\mathrm{H}$ yang diambil 
maka semakin kecil kandungan flavonoid dan polifenol yang terukur. Tingkat ketahanan senyawa flavonoid dan polifenol terhadap kerusakan faktor eksternal, bergantung pada sejauh mana senyawa flavonoid dan polifenol dalam bahan alam memiliki gugus $\mathrm{OH}$ agar setiap senyawa didalamnya dapat berikatan kuat dengan hidrogen sehingga untuk memutuskan ikatan tersebut diperlukan energi yang kuat (Sulaksono dan Syamsudin, 2012).

Penambahan $\mathrm{AlCl} 3$ dapat mengkompleks senyawa golongan flavon (krisin, apigenin, dan luteolin) dan flavonol (kuersetin, mirisetin, morin, dan rutin), namun tidak dapat mengkompleks golongan flavanon dan flavanonol. Flavonoid merupakan senyawa polifenol yang memiliki aktivitas antioksidan (Sasmita, 2019). Atom hidrogen pada struktur senyawa flavonoid dapat meredam radikal bebas dengan menghambat menghambat peroksidasi lipid, dan menekan kerusakan jaringan (Hidayah, 2019).

\section{Hasil Analisa Aktivitas Antioksidan DPPH}

Berdasarkan analisa sidik ragam, diketahui bahwa konsentrasi jintan hitam berbeda nyata $(p<0,01)$ terhadap aktivitas Antioksidan DPPH. hasil analisa menunjukkan nilai aktivitas antioksidan terbesar pada perlakuan jinten hitam 0\% sebesar 49.08ppm, sedangkan aktivitas antioksdian terkecil pada perlakuan jinten hitam $8 \%$ sebesar $44.97 \mathrm{ppm}$. Selisih dari setiap perlakuan $0,78 \mathrm{ppm}-$ $2,86 \mathrm{ppm}$.

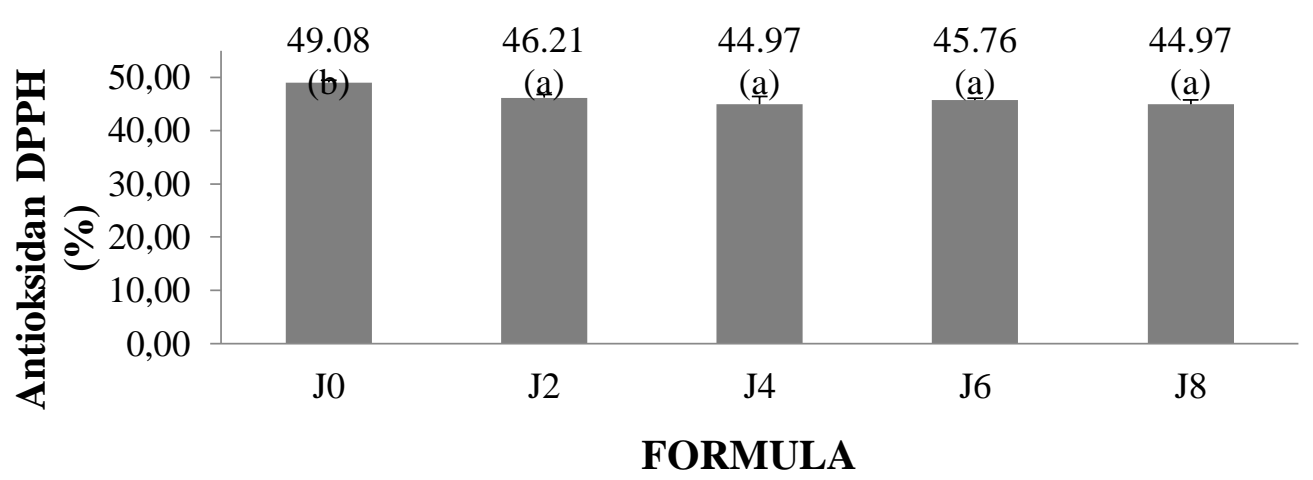

Gambar 5. Histogram analisa aktivitas antioksidan metode DPPH

Keterangan : J0 : jinten hitam 0\%, J2 : jinten hitam 2\%, J4 : jinten hitam 4\%, J6 : jinten hitam $6 \%$ dan J8 : jinten hitam 8\%.

Prinsip pengujian DPPH ialah radikal organik yang stabil dengan warna ungu cukup kuat, pengukuran antioksidan metode ini didasarkan dengan penangkapan radikal oleh antioksidan sehingga warna ungu dari radikal memudar. Nilai aktivitas antioksidan pada semua perlakuan bisa dikatakan sangat kuat hal ini dikarenakan nilai $\mathrm{IC}_{50}<50 \mathrm{ppm}$ (Molyneux, 2004) menyatakan bahwa antioksidan bersifat sangat kuat jika nilai $\mathrm{IC}_{50}<50 \mathrm{ppm}$, bersifat kuat 
apabila nilai $\mathrm{IC}_{50}$ berkisar 50 - 100 ppm, bersifat sedang apabila $\mathrm{IC}_{50}$ 100-150 ppm, bersifat lemah apabila IC 50 150-200 ppm dan sangat lemah dengan $\mathrm{IC}_{50}$ lebih dari 200 ppm.

Kandungan minyak atsiri pada bahan merupakan salah satu senyawa antioksidan yang terdapat pada bahan jamu selokarang seperti jahe, kunyit, temulawak, daun sirsak, pala, ketumbar dan bawang putih memiliki kandungan minyak atsiri yang termasuk golongan antioksidan yang mampu meniadakan ataupun menangkal radikal bebas yang masuk dalam tubuh manusia. Selain kurkuminoid dan minyak atsiri yang berperan sebagai antioksidan pada temulawak menyebutkan bahwa senyawa fenol bisa berfungsi sebagai antioksidan karena kemampuannya meniadakan radikal - radikal bebas dan radikal peroksida sehingga efektif dalam menghambat oksidasi lipida (Nugraha, 2015).

Penurunan aktivitas antioksidan DPPH berhubungan dengan pengujian antioksidan cocok untuk senyawa yang bersifat polar karena kristal DPPH hanya dapat larut dan memberikan absorbansi maksimum pada pelarut etanol ataupun metanol. Pada analisa jamu selokarang + jinten hitam pelarut yang digunakan ialah etanol akan tetapi terjadi penurunan aktivitas antioksidan hal ini dapat disebebkan oleh beberapa hal seperti suhu, pH dan kadar air.

Suhu pengeringan bahan sebelum analisa dapat menyebabkan beberapa kandungan bahan mengalami penurunan hal ini dikarenakan sifat antioksidan yang peka terhadap oksigen sehingga mudah untuk mengalami oksidasi pada saat bahan bereaksi dengan oksigen (Utami, 2009) mengemukakan bahwa polifenol mempunyai sifat asam, mudah teroksidasi, mudah menguap, sensitif terhadap cahaya dan oksigen, serta bersifat antiseptik. Senyawa polifenol dapat berfungsi sebagai antioksidan karena kemampuannya meniadakan radikal-radikal bebas dan radikal peroksida sehingga efektif dalam menghambat oksidasi lipida.

\section{Hasil Analisa Aktivitas Antioksidan FRAP}

Berdasarkan analisa sidik ragam, diketahui bahwa konsentrasi jintan hitam berbeda nyata $(\mathrm{p}<0,01)$ terhadap aktivitas Antioksidan metode FRAP (Ferric Reducing Antioxidant Power). Hasil analisa menunjukkan nilai aktivitas antioksidan terbesar pada perlakuan jinten hitam 0\% sebesar 26,253 mgAAE/L, sedangkan aktivitas antioksdian terkecil pada perlakuan jinten hitam $8 \%$ sebesar 22,116 mgAAE/L. Selisih dari setiap perlakuan $\pm 0,357 \mathrm{mgAAE} / \mathrm{L}-2,589$ mgAAE/L. Asam askorbat digunakan sebagai standar karena memiliki gugus hidroksil bebas yang bertindak sebagai penangkap radikal bebas (Pratama, 2018). Asam askorbat digunakan sebagai pembanding dikarenakan berfungsi sebagai antioksidan sekunder yaitu menangkap radikal bebas dan mencegah terjadinya reaksi berantai. Vitamin $\mathrm{C}$ termasuk golongan antioksidan sekunder yang mampu menangkal berbagai radikal bebas ekstraseluler. Hal ini dikarenakan vitamin $\mathrm{C}$ 
mempunyai gugus hidroksi bebas yang bertindak sebagai penangkap radikal bebas dan jika mempunyai gugus polihidroksi akan meningkatkan aktivitas antioksidan (Maryam, 2015).

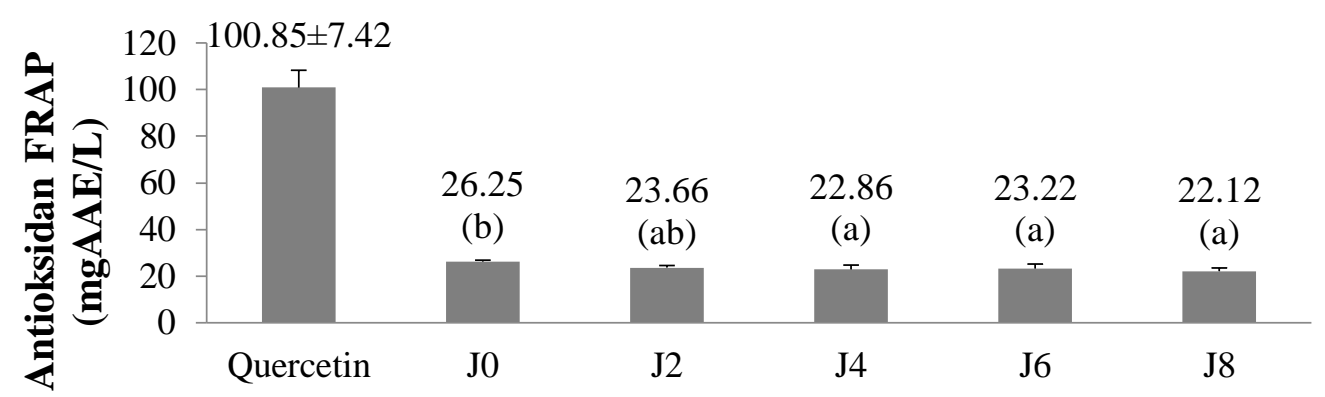

FORMULA

Gambar 6. Histogram analisa aktivitas antioksidan metode FRAP Keterangan : J0 : jinten hitam 0\%, J2 : jinten hitam $2 \%$, J4 : jinten hitam 4\%, J6 : jinten hitam $6 \%$ dan J8 : jinten hitam 8\%.

Prinsip dari uji FRAP adalah reaksi transfer elektron dari antioksidan senyawa $\mathrm{Fe}^{3+}$ menjadi $\mathrm{Fe}^{2+}$. Kekuatan senyawa antioksidan dianalogikan berdasarkan kemampuan mereduksi dari senyawa tersebut. Daya reduksi semakin besar menandakan bahwa semakin besar senyawa mendonorkan elektron dan bereaksi dengan radikal bebas sehingga lebih stabil dan memutus rantai radikal (Nur, 2019). Penambahan TCA agar kompleks kalium ferisianida mengendap. Penambahan $\mathrm{FeCl} 3$ sebagai penghasil Fe3+ dan membentuk senyawa kompleks berwarna biru berlin, serta memperlambat reaksi Fe3+ menjadi Fe2+ yang terjadi sangat cepat oleh pengaruh cahaya (Wabula, 2019). Penurunan aktivitas antioksidan berhubungan dengan minyak atsiri bahan yang mudah menguap pada suhu ruang, jika pada suhu tinggi minyak atsiri tidak mengalami denaturasi hal ini dikarenakan kadar air didalam bahan yang dapat mempertahankan minyak atsiri tidak mengalami denaturasi, minyak atsiri memiliki sifat volatil yang tinggi, sehingga dapat dengan mudah menguap pada suhu ruang tanpa harus melalui pemanasan (Elvianto, 2014).

Penurunan aktivitas antioksidan dapat disebebkan oleh sifat antioksidan sendiri yang rentan terhadap suhu dan $\mathrm{pH}$ perlakuan pendahuluan bahan sebelum dianalisa jamu selokarang dapat menyebabkan bahan mengalami penurunan antioksidan hal ini dikarenakan terjadinya kerusakan sebagian senyawa fenol yang terkandungan pada jintan hitam sehingga mengakibatkan terjadinya penurunan aktivitas antioksidan pada jamu selokarang yang dicampurkan oleh jintan hitam. Senyawa fenol bisa berfungsi sebagai antioksidan karena kemampuannya meniadakan radikal - radikal bebas dan radikal peroksida sehingga efektif dalam menghambat oksidasi lipida (Sukardi, 2002). 


\section{KESIMPULAN}

Adapun kesimpulan dari penelitian ini ialah Jamu selokarang dengan formulasi jinten hitam ( Nigella sativa) berbeda - beda memiliki aktivitas antioksidan, total fenol dan total flavonoid yang berbeda - beda pada setiap perlakuan yang diujikan. Perlu memilih metode yang lebih tepat pada penelitian ini untuk mencegah beberapa senyawa yang terkandung didalam bahan mengalami oksidasi dan denaturasi dikarenakan panas dan kontak langsung dengan oksigen selain itu perlu juga analisa bahan untuk mengetahui kualitas bahan sebelum diolah menjadi jamu. hasil kadar air, kadar abu, dan senyawa antioksidan dapat dikatakan berpengaruh nyata akan tetapi untuk senyawa fenol dan flavonoid dapat dikatakann tidak berpengaruh nyata.

\section{REFERENSI}

Akbar. Analisis Parameter Mutu dan Kadar Flavonoid Pada Produk Teh Hitam Celup. Skripsi . Universitas Pasundan Bandung. 2016

Al-Owaisi, M., N. Al-Hadiwi, S.A. Khan. 2014. GC-MS analysis, determination of total phenolics, flavonoid content and free radical scavenging activities of various crude extracts of Moringa peregrina (Forssk.) Fiori leaves. Asian Pacific Journal of Tropical Biomedicine, 4(12): 964-970.

Andarwulan, N, Kusnandar, F, Herawati, D. 2011. Analisis Pangan. Dian Rakyat. Jakarta.

Arifin, A.S., N.D. Yuliana, M. Rafi. 2019. Aktivitas Antioksidan pada Beras Berpigmen dan Dampaknya terhadap Kesehatan. Artikel. Bogor: IPB

Azizah, D.N. dan Faramayuda, F., 2014. Penetapan Kadar Flavonoid Metode AlCl3 Pada Ekstrak Metanol Kulit Buah Kakao (Theobroma Cacao L.). Kartika Jurnal Ilmiah Farmasi, 2(2).

Badan Pengawas Obat dan Makanan Republik Indonesia (BPOM RI). 2019. Peraturan BPOM Nomor 32 Tahun 2019 Persyaratan Keamanan Dan Mutu Obat Tradisional. Jakarta: Kepala Pengawas Obat dan Makanan Republik Indonesia.

Dimas, T. P. 2008. Teh dan Pengolahannya. Universitas Brawijaya Press. Malang.

Desi, I.K. 2014. Penetapan kandungan fenolik total dan uji aktivitas antioksidan dengan metode dpph (1,1-diphenyl-2-pikrilhydrazil) ekstrak metanolik umbi bidara upas (Merremia mammosa (Lour) Hallier f.). Skripsi. Universitas Sanata Dharma Yogyakarta

Daryono, E.D., A.T, Pursitta., A, Isnain. 2014. Ekstraksi Minyak Atsiri Pada Tanaman Kemangi Dengan Pelarut N-Heksana. Jurnal Teknik Kimia Vol.9, No.1: 1-7 
Ghasemzadeh, A., Jaafar H.Z.E. and Rahmat, A. 2010. Antioxidant Activities, Total Phenolics and Flavonoids Content in Two Varieties of Malaysia Young Ginger (Zingiber officinale Roscoe). Molecules, 15: 4324-4333. doi:10.3390/molecules 15064324

Hidayah, N., A.H. Alimuddin, Harlia. 2019. Aktivitas Antioksidan dan Kandungan Fitokimia dari Ekstrak Kulit Buah Pinang Sirih Muda dan Tua (Areca catechu L.). Jurnal Kimia Khatulistiwa, 8(2): 52-60.

Haeria, Hermawati, A.T. Ugi Dg. Pine. 2016. Penentuan Kadar Flavonoid Total dan Aktivitas Antioksidan Ekstrak Etanol Daun Bidara (Ziziphus spinachristi L.). J. of Pharmaceutical and Medicinal Sciences, 1(2): 57-61.

Mulia, K., A.E.Z, Hasan., Suryani. 2016. Total Fenolik, Aktivitas Antikanker dan Antioksidan Ekstrak Etanol Cabe Jawa (Piper retrofractum Vahl) dari Pamekasan dan Karang Asem. Current Biochemistry. Volume 3 (2): 80 - 90

Maryam, M. Baits, A. Nadia. 2015. Pengukuran Aktivitas Antioksidan Ekstrak Etanol Daun Kelor (Moringa oleifera Lam.) Menggunakan Metode FRAP (Ferric Reducing Antioxidant Power). Semarang, Universitas Muslim Indonesia.

Nugraha, A. A. Kawiji. dan W. Atmaka. 2015. Kadar Kurkuminoid, Total Fenol dan Aktivitas Antioksidan Oleoresin Temulawak (Curcuma xanthorrhiza) dengan Variasi Teknik Pengeringan dan Warna Kain Penutup. Biofarmasi, 13(1): 6-14.

Nur, S., F.J. Sami, Wilda R., A. Awaluddin, M.I.A. Afsari. 2019. Korelasi Antara Kadar Total Flavonoid dan Fenolik dari Ekstrak dan Fraksi Daun Jati Putih (Gmelina arborea Roxb.) terhadap Aktivitas Antioksidan. J. Farmasi Galenika, 5(1): 33-42.

Oktaviana, Prima Riska. 2010. Kajian Kurkumoid, Total Fenol, dan Aktivitas Antioksidan Ekstrak Temulawak pada Berbagai Teknik Pengeringan dan Proporsi Pelarut. Skripsi. Fakultas Pertanian UNS.

Pratama, V.B. 2019. Isolasi, Karakterisasi, dan Uji Aktivitas Antioksidan Senyawa Asam Klorogenat dari Biji Kopi Hijau Robusta (Coffea canephora Pierre ex A. Froehner). Skripsi. Bandar Lampung: Universitas Lampung.

Sasmita, S.O., L. Purwanti, E.R. Sadiyah. 2019. Perbandingan Aktivitas Antioksidan Ekstrak Etanol Daun, Kulit Buah dan Biji Kopi Arabika (Coffea arabica L.) dengan Metode Peredaman Radikal Bebas DPPH. Prosiding Farmasi, 5(2): 699-705.

Sulaksono, F. B. dan Syamsudin. 2012. Koreksi Kadar Flavonoid dan Toksisitas dalam Ekstrak Tempuyung (Sonchus Arvensis) dan Pegagan (Centella Asiatica). Jurnal Konversi 1(2): 33-42.

Utami, T.S., R., Arbianti, H., Hermansyah, A., Reza, 2009. Perbandingan Aktivitas Antioksidan Ekstrak Etanol Daun Simpur (Dillenia indica) dari Berbagai 
Metode Ekstraksi dengan Uji ANOVA. Prosiding Seminar Nasional Teknik Kimia Indonesia, Bandung

Vifta, R.L., F.P. Luhurningtyas. 2020. Nanoparticle from Medinilla speciosa with Various of Encapsulating Agent and Their Antioxidant Activities Using Ferric Reducing Assay. IJCC, 11(1): 22-29.

Wabula, R.A., Seniwati, H. Widiastuti. 2019. Aktivitas Antioksidan Ekstrak Etanol Buah Merah (Pandanus conoideus Lam.) dengan Metode Ferric Reducing Antioxidant Power (FRAP). Jurnal Kesehatan, 2(4): 329-337.

Widjanarko A., Ridwan, Djaeni M., Ratnawati, 2012, Penggunaan zeolit sintetis dalam pengeringan gabah dengan proses fluidisasi indirect contact. Jurnal Teknologi Kimia dan Industri, 2 (2) :103- 110. 